\title{
Dynamics of Toxorhynchites splendens population in the Larval phase at a rubber plantation in Banjarbaru, South Kalimantan, Indonesia
}

\author{
MUHAMAT ${ }^{1,2, \bullet}$, SUWARNO HADISUSANTO ${ }^{3}$, SITTI RAHMAH UMNIYATI ${ }^{4}$, R.C. HIDAYAT SOESILOHADI ${ }^{5}$ \\ ${ }^{1}$ Faculty of Biology, Universitas Gadjah Mada. Jl. Teknika Selatan, Sekip Utara, Sleman 55281, Yogyakarta, Indonesia \\ ${ }^{2}$ Departement of Biology, Faculty of Mathematics and Sciences, Lambung Mangkurat University. Jl. A. Yani Km 36 Banjarbaru 70714, South \\ Kalimantan, Indonesia. Tel./fax.: +62-511 -4773112, ’email: muhamat@ulm.ac.id \\ ${ }^{3}$ Division of Laboratory of Ecology, Faculty of Biology, Universitas Gadjah Mada. Jl. Teknika Selatan, Sekip Utara, Sleman 55281, Yogyakarta, Indonesia \\ ${ }^{4}$ Department of Parasitology, Faculty of Medicine, Universitas Gadjah Mada. Jl. Teknika Selatan, Sekip Utara, Sleman 55281, Yogyakarta, Indonesia \\ ${ }^{5}$ Division of Laboratory of Entomology, Faculty of Biology, Universitas Gadjah Mada. Jl. Teknika Selatan, Sekip Utara, Sleman 55281, Yogyakarta, \\ Indonesia
}

Manuscript received: 9 August 2021. Revision accepted: 21 October 2021

\begin{abstract}
Muhamat, Hadisusanto S, Umniyati SR, Soesilohadi RCH. 2021. Dynamics of Toxorhynchites splendens population in the Larval phase at a rubber plantation in Banjarbaru, South Kalimantan, Indonesia. Biodiversitas 22: 4915-4922. This study aims to describe a water-filled rubber sap bowl as a habitat for larval Toxorhynchites splendens. The research used a quota drive count method, taking the first 10 rubber sap bowls found in the study area: (i) with larval Tx. splendens, (ii) with other mosquito larvae, (iii) with water but without mosquito larvae, and (iv) without water. The number of larval Tx. splendens was calculated based on the developmental phase and other mosquito larvae present in each bowl. Environmental factors, such as temperature and humidity, rainfall, wind velocity, and duration of irradiation were the additional data. The results of this study showed that the average frequency of On average, over $20 \%$ of bowls contained larval $T x$. splendens, and the percentage increased in high rainfall. During low rainfall in August and September, Tx. splendens used water-filled rubber sap bowls as breeding places. This study concludes that Tx. splendens can make use of water-filled rubber sap bowls as places for breeding. Each rubber sap bowl contained one or more individuals of instar larvae 2, and the number decreased as the developmental phase continued because of the limited volume of water in the bowl, cannibalism, and the number of other mosquito larvae as prey.
\end{abstract}

Keywords: Cannibalism, larval Tx. splendens, rubber sap bowl, predator, rainfall

\section{INTRODUCTION}

In general, the populations of Anopheles, Aedes and Culex mosquitoes in rural areas can still be reduced by various controlling organisms. This is a sign that the population balance is still maintained between mosquitoes and controlling organisms. These controlling organisms can be predators, parasites and entomopathogens (Saleeza et al. 2014; Benelli et al. 2016; Udayanga et al. 2019). Several insect orders are predators of mosquito larvae, namely Coleoptera, Odonata, and Diptera (Dida et al. 2015; Udayanga et al. 2019; Couret et al. 2020; Eba et al. 2021).

Diptera orders as predators mosquito larvae include species Toxorhynchites spp. and Lutzia spp. (Moirangthem et al. 2018; Dinithi and Hemantha 2020). Both mosquitoes can be considered as part of integrated vector control. However, to fulfill their energy requirements, Toxorhynchites spp. mosquitoes only suck plant fluids, while female Lutzia spp. mosquitoes still suck blood (Pramanik et al. 2016). This is a consideration for Lutzia spp to be developed as part of integrated mosquito control.

Elephant mosquitoes or Toxorhynchites are widely found in tropical and subtropical regions. Twenty-four species of Toxorhynchites mosquitoes live in Asia, including 12 species found in Indonesia (Tyagi et al. 2015). These large mosquitos are characterized by a body length of $\pm 20 \mathrm{~mm}$, while instar larvae can have a body length of $\pm 12 \mathrm{~mm}$ (Millado et al. 2017).

Toxorhynchites mosquito larvae are predators of other mosquito larvae (Aditya et al. 2007). During the developmental phase, Toxorhynchites larvae can hunt up to 300 other mosquito larvae (Collins and Blackwell 2000). Toxorhynchites larvae can naturally be found in tree holes flooded with water (Donald 2020). These mosquitoes can also be found in man-made water containers, such as tires, bottles, and drums (Zavortink and Poinar 2008; Mohamad and Zuharah 2014).

Rubber plants are common plantation crops in tropical regions, including Indonesia, data reported that the area of rubber plantations in Indonesia reached 2.8 million hectares in 2018 (Amalia et al. 2020). The expansion of rubber plantations provides new habitats for various species of mosquitoes. Several species of mosquitoes that can adapt to rubber plantations, such as Aedes albopictus and Anopheles $s p$., become vectors of diseases for humans (Jomon and Valamparampil 2014; Kaewwaen and Bhumiratana 2015).

The sap collection bowl is an important harvesting tool for rubber farmers (Nasruddin and Bahri 2019). The frequently used latex sap bowls are filled with a rubber crust, making them no longer effective to store new latex sap; and therefore, they are replaced with other bowls. However, the old bowls are usually placed around the 
rubber plantation area; and thus, in the rainy season, those bowls are filled with rainwater, becoming new breeding places for mosquitoes. An increase in mosquito breeding places is followed by a rise in the population of various mosquito species (Kaewwaen and Bhumiratan 2015; Lestari et al. 2020; Rahma et al. 2020). Otherwise, in the dry season, water in the latex sap bowls evaporates and dries up, reducing many breeding places for various species of mosquitoes, which later causes their population to decline.

Toxorhynchites larvae found in latex sap bowls from the rubber plantation in Banjarbaru are $T x$. splendens (Muhamat et al. 2020). Tx. splendens population in rubber plantation areas are closely related to the number of waterfilled latex sap bowls and other mosquito populations. Therefore, this study discusses the fluctuation in the $T x$. splendens population at the larval phase and other species of mosquito larvae in latex sap bowls in the rubber plantation in Banjarbaru, South Kalimantan.

\section{MATERIALS AND METHODS}

This research was conducted in 10 locations of rubber plantations in the villages of Gunung Kupang (GK), Sungai Ulin (SU), and Padang Panjang (PP) in the area around Banjarbaru, South Kalimantan Province, Indonesia. The environmental profile of each location is presented in Table 1 and Figures 1 and 2. This study was conducted from April to October 2020. The research method used was a purposive random sampling method, namely rubber plantations that had not been tapped for a long time. Observations were made on the rubber sap bowl attached to the rubber tree and on the garden floor in the rubber plantation. The sap bowls that were sampled were grouped based on the presence or absence of mosquito larvae and the water content in the bowl into 5 groups, namely: (i) a rubber sap bowl containing larval Tx. splendens only; (ii) a rubber sap bowl containing larval $T x$. splendens and other mosquito larvae; (iii) a rubber bowl containing larval $T x$. splendens and other mosquito larvae; (iv) a rubber sap bowl containing only water; and (v) a rubber sap bowl that is not filled with water. The method of determining the number of rubber sap bowls as a sample is by using the quota drive account method, that is, from each location, the 100 bowls that are the fastest are found. The bowls containing water were observed and if any larvae were found, they were taken with a pipette and/or filtered using a 30 mesh filter. The filtered larvae were put into bottles and then brought to the Basic Laboratory of Lambung Mangkurat University, Indonesia for species identification with mosquitos identification keys according to Rattanarithikul et al. 2007; Farajollahi and Price 2013. Environmental variables in the form of temperature, humidity, rainfall, duration of irradiation, and wind speed came from the Banjarbaru BMKG class 1 station. Field observations were 2 times a month with a sampling distance of 14 days.

The number of rubber sap bowls observed was classified according to the above classification, the frequency of encounters was calculated and presented in the form of graphic images. Observations on mosquito larvae in the bowl were grouped into 2 groups, namely the Tx larval group. splendens and other mosquito larvae. Larval $T x$. splendens were grouped into 4 stages of life, namely (i) to instar 2, (ii) instar 3, (iii) instar 4, and (iv) pupae and counted the number of individuals, while for larval from other mosquito species, only the number of individuals was counted. Number of larval Tx. splendens sap bowl as a place of growth and development of larval Tx. splendens is presented in the form of monthly frequency graphs. Frequency of encountering bowls containing larval $T x$. splendens with other mosquito larvae and the frequency of bowl encounters where there are only other mosquito larvae are presented in the form of graphic images. Based on the larval life phase of $T x$. splendens, larval encounter frequency $T x$. splendens, either with other mosquito larvae or not with other mosquito larvae and the number of bowl larvae each month are presented in the form of graphic images.

Selection of rubber sap bowls as a place for laying eggs $T x$. splendens is known from comparing the average number of other mosquitoes larval in the bowl containing larval Tx. splendens with other mosquito larvae with the number of other mosquito larvae in the bowl without larval Tx. splendens. Both data were subjected to Bartlett test to determine the homogeneity of the data and continued with the T-test. Data on environmental factors and the number of larval Tx. splendens obtained every month were tested for normality of Lilliefors followed by Pearson's correlation analysis. The results of this test are to determine the relationship between environmental factors and the monthly population of larval $T x$. splendens.

Table 1. Sampling locations

\begin{tabular}{llll}
\hline \multirow{2}{*}{ Location } & \multicolumn{2}{c}{ Coordinate } & Environmental profile \\
\cline { 2 - 3 } & -3.4827524 & 114.8691732 & $\begin{array}{l}\text { There are some houses in the area. The area is far from water sources, such as } \\
\text { rivers, lakes, and pools. }\end{array}$ \\
GK1 & -3.4886562 & 114.8892642 & $\begin{array}{l}\text { The area is close to chicken coops. } \\
\text { GK2 }\end{array}$ \\
GK3 & -3.488188 & 114.883477 & The area is close to houses and rice fields. \\
GK4 & -3.490113 & 114.8767416 & The area is close to water sources, such as lakes. \\
GK5 & -3.490113 & 114.876741 & The area is far from houses but near water sources, such as rivers. \\
MA & -3.464463 & 114.906883 & The area is close to swampy rice fields. \\
PP1 & -3.464330 & 114.914174 & The area is near the chicken coops and water sources. \\
PP2 & -3.46607 & 114.9117217 & The area is near the water sources. \\
PP3 & -3.457512 & 114.913265 & The area is near the chicken coops, houses, and rice fields. \\
PP4 & -3.457512 & 114.913265 & The area is far from water sources. \\
\hline
\end{tabular}




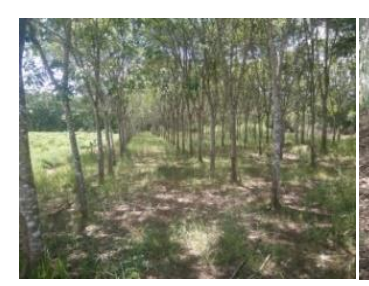

GK1

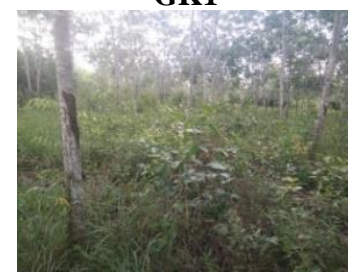

MA1

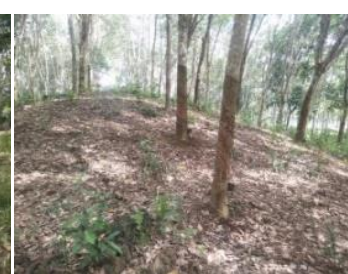

GK2

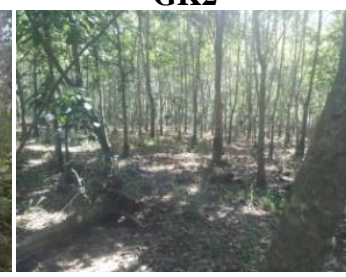

PP1

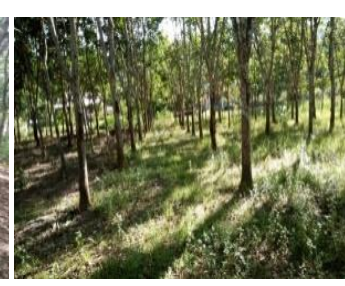

GK3

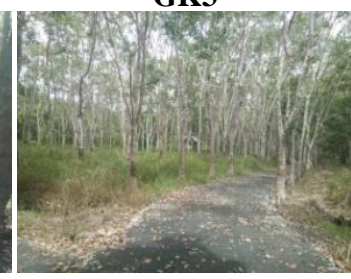

PP2

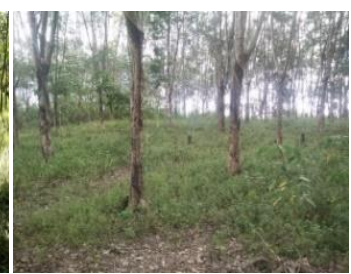

GK4

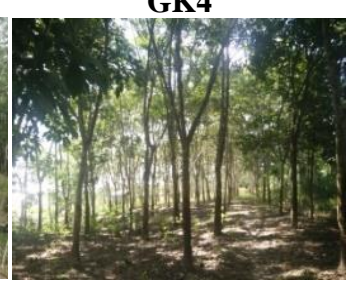

PP3

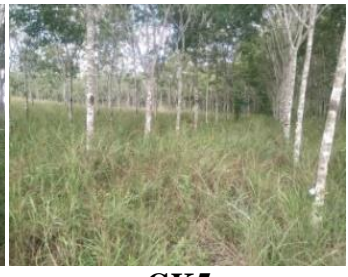

GK5

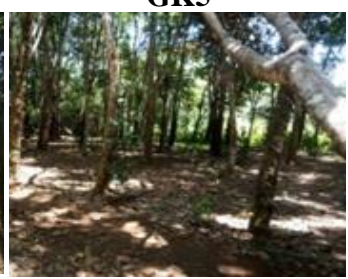

PP4

Figure 1. Location sample station
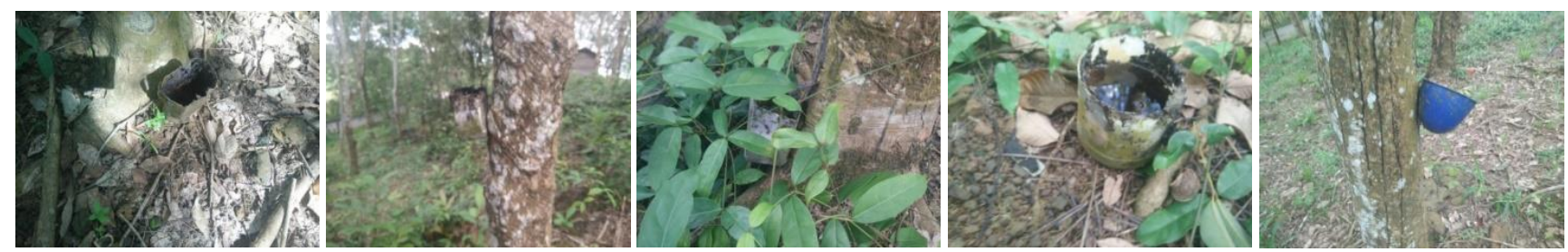

Figure 2. Condition and position of the bowl on the rubber tree

\section{RESULTS AND DISCUSSION}

\section{Results}

The presence of $T x$. splendens in rubber plantations can be estimated from the frequency of meeting rubber sap bowls containing larval $T x$. splendens. The results of observations on the frequency of obtaining rubber sap bowls with larval Tx. splendens in 10 research locations in Banjarbaru, from April to October 2020, are as the following. From April to July, 48\%-83\% of rubber sap bowls contained Tx. splendens. Between August and September, rubber sap bowls containing water were only found in one location, with $20 \%$ and $31 \%$, while on October, $7-25 \%$ of rubber sap bowls contained $T x$. splendens (Figure 3). Observations were also made on rubber sap bowls containing mosquito larvae without larval $T x$. splendens with the percentage of meeting frequency of 20\%-80\% in April-September and 100\% in October, with the presence of other mosquito larvae (Figure 4).

The weather in the observation site affects the volume of water in the rubber sap bowls. Rainfall in April to June was high, decreased in July-August, and then increased again in September-October. The duration of irradiation increased in August and then decreased in September and October, while the wind velocity increased from July to October. Temperature fluctuation during the study was not high, while the air humidity decreased from July to October (Figure 5). The combination of a decrease in air humidity $(\mathrm{r}=0.95)$ and rainfall $(\mathrm{r}=0.44)$, and an increase in wind velocity $(r=-0.81)$ led to an increase in evaporation of water in the rubber sap bowls (Table 2), causing the water in the rubber sap bowls to decrease and even run out (Figure 6).

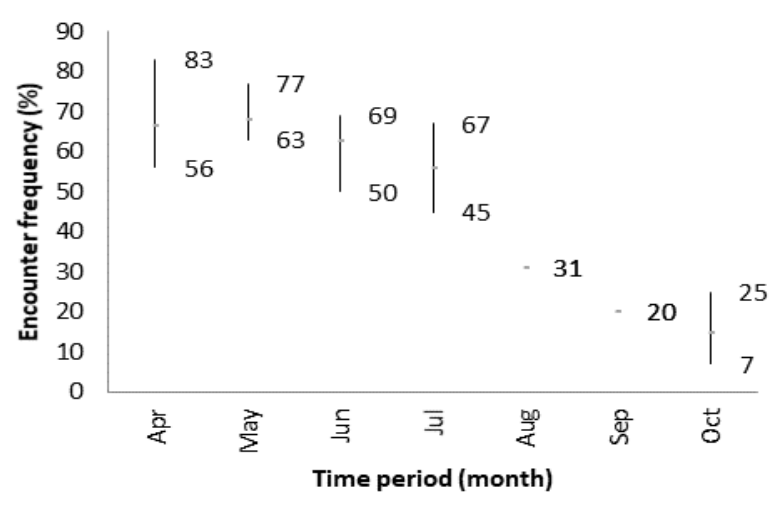

Figure 3. Percentage of rubber sap bowls containing larval $T x$. splendens

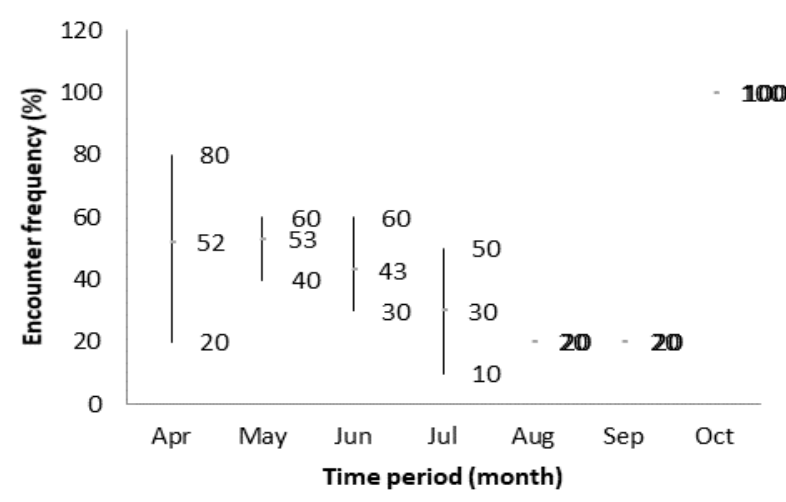

Figure 4. Percentage of rubber sap bowls containing mosquito larvae without larval $T x$. splendens 


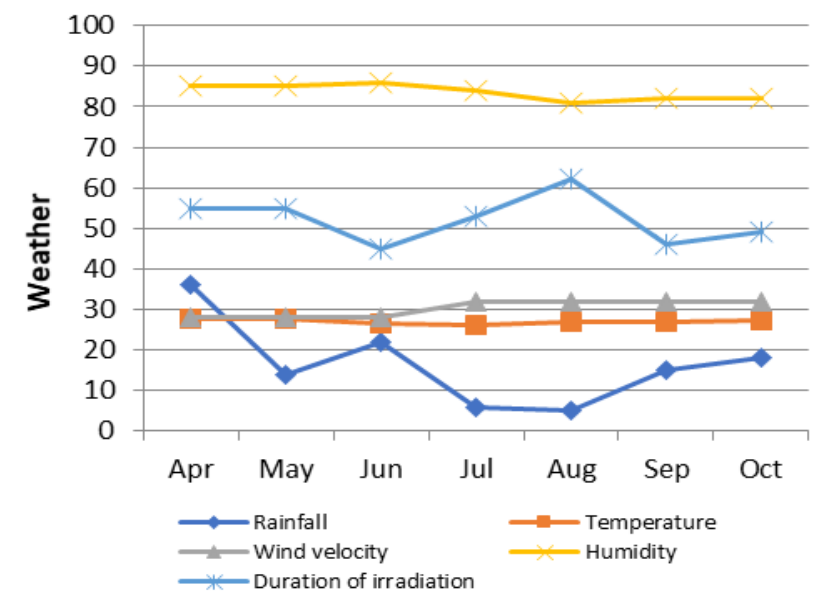

Figure 5. The weather around Banjarbaru (source: analyzed data from Banjarbaru BMKG station)

Pearson's correlation test on discovery frequency of rubber sap bowls containing larval $T x$. splendens and those containing other mosquito larvae without larval $T x$. splendens in April and May resulted in very strong and strong correlations, respectively. However, the correlation became weak and negative in June. The correlation was moderately negative both in July and October. The correlation in August and September could not be estimated because the rubber sap bowl contained water and larval Tx. splendens was only found in one location (Table 3).

The average number of other mosquito larvae in a rubber sap bowl containing larval $T x$. splendens was between 14 and 50.5 (Figure 7). Meanwhile, a bowl without larval $T x$. splendens contained 11.5 to 64 larvae (Figure 8$)$. The T-test at the $5 \%$ level $(p$-value $=0.13)$ of the two conditions did not show any differences in the number of larvae.

The presence of other mosquito larvae in a rubber sap bowl ensures the food availability for $T x$. splendens larvae that will develop into pupae. The results of observation on the discovery frequency of rubber sap bowl containing $2^{\text {nd }}$

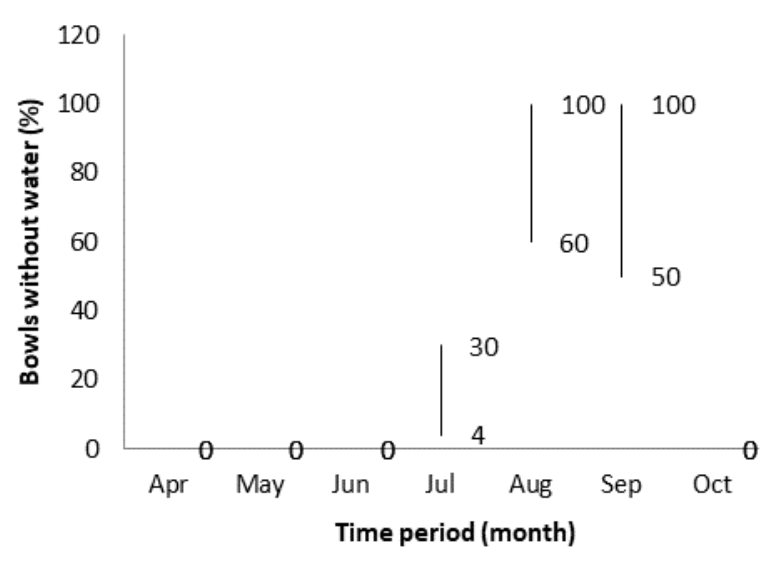

Figure 6. The percentage of meeting rubber sap bowls without water from April to October

instar larvae showed that the instar larvae remained with another mosquito larvae. Observation on rubber sap bowl containing $3^{\text {rd }}$ instar larvae and other mosquito larvae conducted from April to July demonstrated a higher frequency of encounter, compared to the bowl containing only Tx. splendens. However, from August to July, more bowls contained only $3^{\text {rd }}$ instar larvae. The number of bowls containing $3^{\text {rd }}$ instar larvae and other mosquito larvae reached $100 \%$.

The number of bowls containing $T x$. splendens $4^{\text {th }}$ instar larvae and pupa together with another mosquito larvae from April to September was fewer than the number of bowls containing only Tx. splendens (Figure 9).

The number of rubber sap bowls containing larval $T x$. splendens with another mosquito larvae for $3^{\text {rd }}$ instar larvae during the observation was more dominating than that of bowls with individuals in other phases of life. The rubber sap bowl containing $4^{\text {th }}$ instar larvae and pupa was smaller in number (Figure 10.A). The number of the rubber sap bowl containing $4^{\text {th }}$ instar larvae and pupa without other mosquito larvae was higher (Figure 10.B).

Table 2. The results of Pearson's correlation test on the relationship between the weather and the number of rubber sap bowls containing Tx. splendens in Banjarbaru

\begin{tabular}{llccccc}
\hline & Air & Rainfall & $\begin{array}{c}\text { Air } \\
\text { temp. }\end{array}$ & $\begin{array}{c}\text { Wind } \\
\text { velocity }\end{array}$ & $\begin{array}{c}\text { Irradiation } \\
\text { duration }\end{array}$ & $\begin{array}{c}\text { Multiple } \\
\text { correlations }\end{array}$ \\
\hline $\begin{array}{l}\text { The number of bowls } \\
\text { containing water }\end{array}$ & $\begin{array}{l}\text { Pearson's Correlation } \\
\text { (p-value }<0.05)\end{array}$ & 0.95 & 0.44 & 0.15 & -0.81 & -0.04 \\
\hline
\end{tabular}

Table 3. The results of Pearson's correlation test on the frequency of discovering the rubber sap bowls containing larval Tx splendens and the rubber sap bowls containing other mosquito larvae

\begin{tabular}{llllll}
\hline Month & $\begin{array}{l}\text { Pearson's correlation }(\mathbf{r}) \\
(\mathbf{p} \text {-value }<\mathbf{0 . 0 5})\end{array}$ & Month & $\begin{array}{l}\text { Pearson's } \\
\text { correlation }(\mathbf{r})\end{array}$ & Description of r score & Interpretation \\
\hline April & 0.85 & August & - & $0-1.99$ & Very weak \\
May & 0.72 & September & - & $2.00-3.99$ & Weak \\
June & -0.02 & October & -0.54 & $4.00-5.99$ & Fair \\
July & -0.48 & & & $6.00-7.99$ & Strong \\
& & & & $8.00-10.00$ & Very strong \\
\hline
\end{tabular}




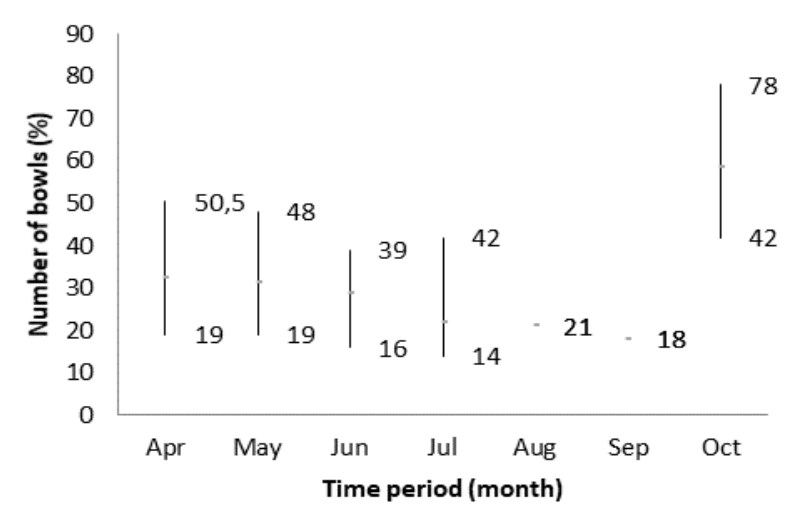

Figure 7. The average number of other mosquito larvae in rubber sap bowls containing larval Tx. splendens

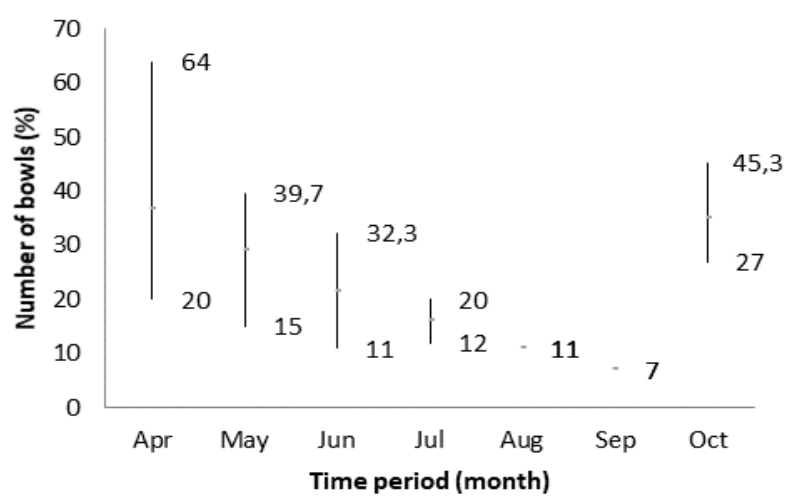

Figure 8. The average number of other mosquito larvae in rubber sap bowls without larval $T x$. splendens

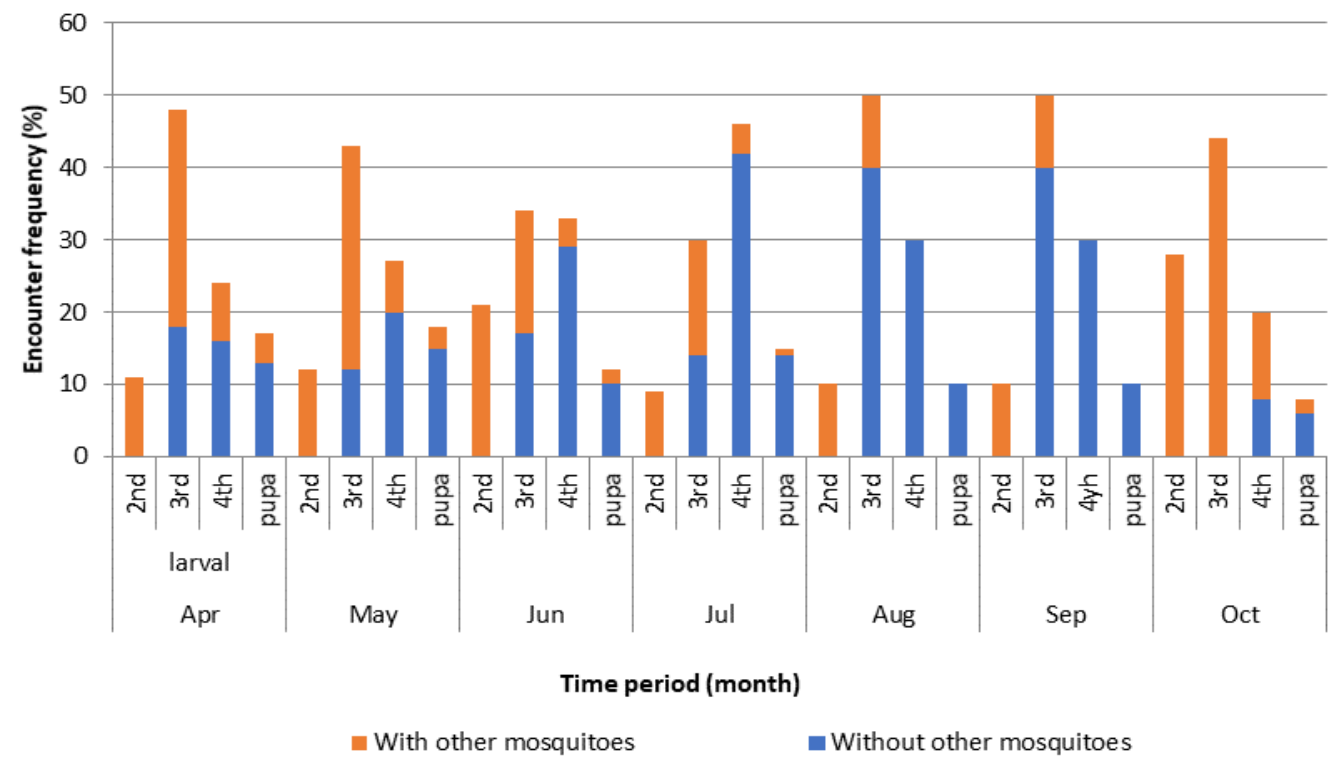

Figure 9. The comparison of the number of bowls containing Tx. splendens along with other mosquito larvae and the number of bowls containing only larval Tx. splendens

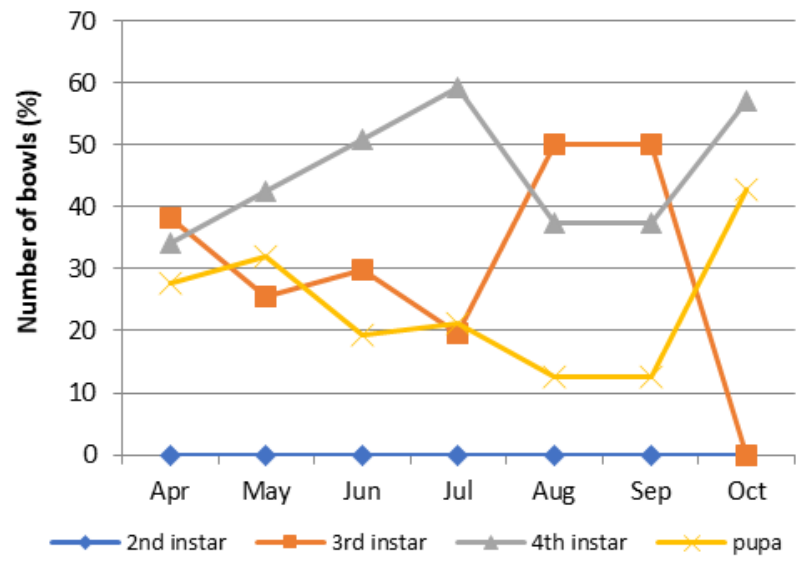

A

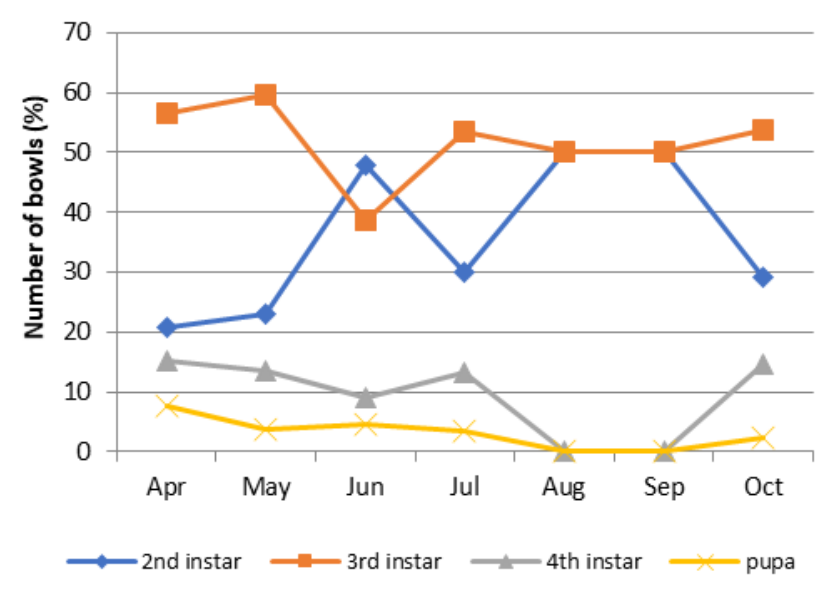

B

Figure 10. The number of (A) bowls containing Tx. splendens along with other mosquito larvae, and (B) bowls containing only larval Tx. splendens 


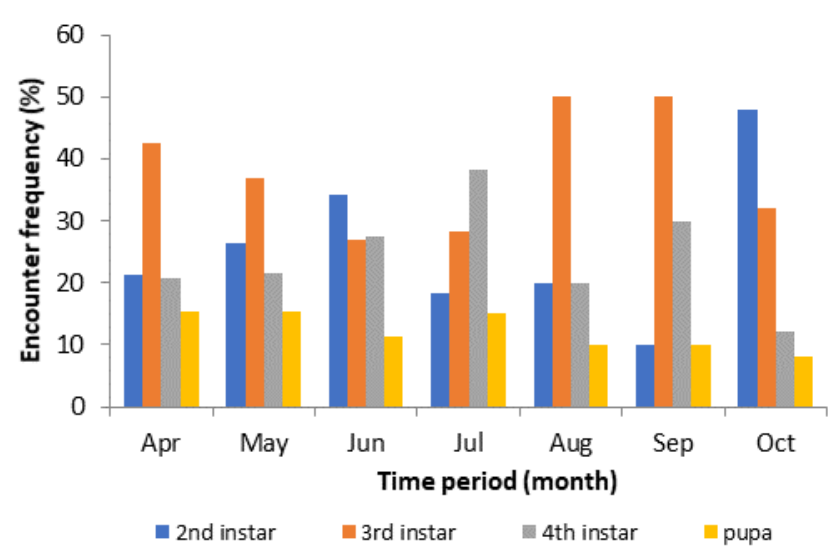

Figure 11. The percentage of the number of larval Tx. splendens in rubber sap bowl

The ease of discovering Tx. splendens larvae and pupae in rubber plantations depicted the development phase of the larvae and pupae in various rubber sap bowls. The most frequently met bowls contained larval $T x$. splendens $3^{\text {rd }}$ instar larvae, followed by $2^{\text {nd }}$ and $4^{\text {th }}$ instar larvae (Figure 11). The highest average number of larvae or pupae in each bowl during the observation was $2^{\text {nd }}$ instar larvae, followed by $3^{\text {rd }}$ instar larvae, $4^{\text {th }}$ instar larvae, and pupa, respectively (Figure 12).

\section{Discussion}

The presence of larval Tx. splendens as a predator of mosquito larvae in an environment is strongly influenced by external factors that work in the environment. The larval phase that lives in water is very sensitive to changes in the volume of water in the container. In this study, population of larval Tx. splendens was observed in the sap bowl of rubber plantations during the rainy and dry seasons.

The results of observations of the frequency of encounters different the rubber sap bowls containing the larval stages of $T x$. splendens and other mosquito larvae can be seen in Figures 3 and 4. Encounters of rubber bowls containing the larval stages of $T x$. splendens and other mosquito larvae in April to July and October more often than August and September. April to July and October are rainy with enough rainfall to keep the sap bowls filled with water. In this month all the sap bowls filled with water are there so that it will maintain the population of both $T x$. splendens and other mosquitoes. The decrease in rainfall in August and September caused many bowls of rubber sap to dry up, resulting in fewer breeding places for mosquitoes (Figure 6). This causes a decrease in the encounter of the rubber sap bowl containing the larval stages of $T x$. splendens. Population fluctuations were also experienced by Aedes albopictus and Anopheles maculatus as the main prey larvae of Tx. splendens (Tangena et al. 2017; Zahouli et al. 2017; Nair and Gayathri 2019; ) The addition and reduction of water-filled containers in rubber plantations will result in increase and decrease in population of various mosquito species (Boonklong and Bhumiratana 2016).

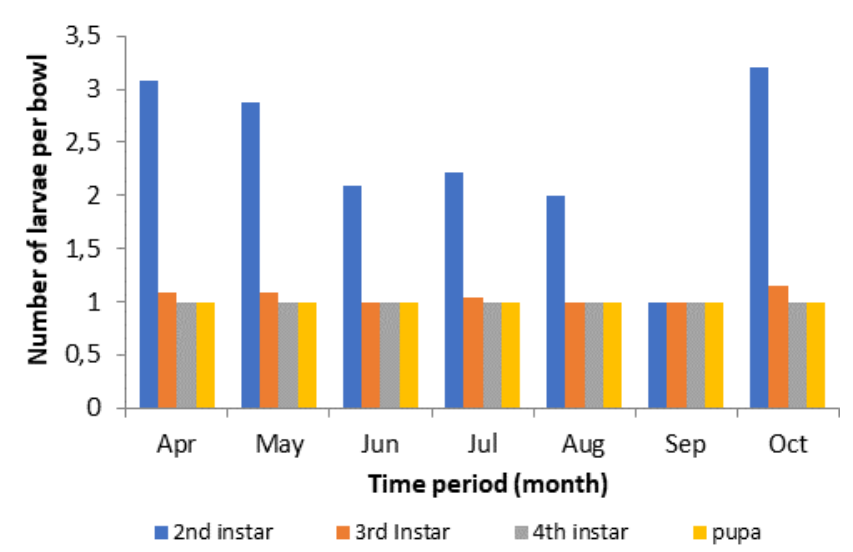

Figure 12. The average number of larval $T x$. splendens in each rubber sap bowl

In general, the dynamics of the mosquito population in an area is strongly influenced by the water condition. The water condition is significantly attributed to the water area, rainfall, evaporation, humidity, air temperature, and wind velocity (Majumder 2014). Air humidity, rainfall, and wind velocity are the environmental factors that play a role in the water condition in rubber plantations (Table 1).

Tx. splendens mosquitoes choose a water container for breeding based on the presence of prey in the container. The selection of the number of prey in the rubber sap bowl can be considered before choosing the bowl as a breeding site. The results of the $F$-test on the rubber sap bowl containing larval $T x$. splendens along with other mosquito larvae and the rubber sap bowl containing only other mosquito larvae do not show any differences (Table 2). This indicates that all sap bowls have an equal opportunity as a breeding place for Tx. splendens. Tx. splendens in choosing a water container as a breeding place is based on the presence of prey first in the container. The selection of the number of prey in the bowl can be considered before choosing a rubber sap bowl as a breeding place (Klecka 2012; Odo et al. 2015).

All sap bowls contained $2^{\text {nd }}$ instar larvae $T x$. splendens that were still with other mosquito larvae (Figure 9). The early developmental period of predators is generally still with prey, the predator's body size affects the ability to prey. The body length of the $2^{\text {nd }}$ instar larvae is almost the same as the $4^{\text {th }}$ instar larvae of other mosquitoes (Millado et al. 2017). With a small body size, $2^{\text {nd }}$ instar larvae only prey on prey whose body size is smaller than themselves. This is common in preying on predatory larvae (Gvoždík and Smolinský 2015; Younes et al. 2015; Venkatesh and Tyagi 2015; Priyadarshana 2021).

Figure 10). Observations of predators in their habitat are strongly influenced by body size (Shultza and Finlayson 2010). The body length of the $3^{\text {rd }}$ instar larvae ranging from 4-8 $\mathrm{mm}$ will be very easy to distinguish from other mosquito larvae (Millado et al. 2017). Other mosquito larvae are still in large numbers so that the cannibalism of $3^{\text {rd }}$ instar larvae has not yet emerged (Figure 
9). These two reasons make $3^{\text {rd }}$ instar larvae more common in every observation.

Rubber sap bowl containing $3^{\text {rd }}$ instar larvae is more frequently found, either containing $3^{\text {rd }}$ instar larvae with the other mosquito larvae or without other mosquito larvae, compared to rubber sap bowl containing $4^{\text {th }}$ instar larvae and pupa. Rubber sap bowls containing $4^{\text {th }}$ instar larvae and pupa at each observation time and location were more often found without other mosquito larvae (Figure 8.B). The preying ability of predatory larvae in the early development period is still low and will continue to grow due to the need for more nutrition (Kundu 2014). As the growth and development of predators increases, the prey is eaten also increases (Altwegg 2003). The limited number of prey causes prey to run out quickly. This will affect the process of further instar development.

The decrease in the number of larvae in August and September is due to the reduced rainfall, resulting in many dry bowls and weather condition that is unsuitable for mosquito reproduction. This is common in larval predators, which are closely related to water volume, such as the predatory larvae of the Platynectes sp. which has decreased population in the dry season (Gowhar 2018).

The percentage of rubber bowl containing Tx. splendens pupa is low, only 1 pupa was found in each bowl. This is because some of the older instar larvae cannot develop into pupae. The need for increased nutritional sources in older instars causes predatory activity to also increase. This also occurs in Harmonia axyridis larvae that prey on Mizus persicae (Endarto and Wuryantini 2019). However, larval $T x$. splendens that live in narrow ponds and limited prey causes many old instar larvae to starve to death.

The average number of larval Tx. splendens in the bowl at each stage are not uniform (Figure 11). The average number of $2^{\text {nd }}$ instar larvae in each rubber sap bowl is more than 1 . The number of Tx. splendens $3^{\text {rd }}$ instar larvae in each bowl are decreasing until reaching 1 individual. In each bowl containing $4^{\text {th }}$ instar larvae and pupae, only 1 individual remains. A small-sized bowl has a smaller carrying capacity as a habitat for larval $T x$. splendens and can only support one larva to develop into a pupa. This is also common in predators that live in confined spaces such as larval populations of Ceriagrion coromandelianum and Platynectes sp. decreased when environmental conditions were unfavorable for prey and predators (Kumar et al. 2014; Payra 2020).

Tx. splendens produce 14 eggs per day on average with 96\% viability (Millado et al. 2017). In the early development phase, the larvae have adequate food. In further development, the larvae of Tx. splendens in the limited area and amount of feed will prey on other mosquito larvae until they run out, and when starving, cannibalism will happen, where the larvae will eat each other (Millado et al. 2017; Soda et al. 2018). This condition happens in a rubber sap bowl containing $4^{\text {th }}$ instar larvae and pupae, which finally only 1 larva left.

The sample locations are rubber plantations that are close to cattle pens, rice fields, and roads that are closely related to human activities. Observations from all locations found larval $T x$. splendens. This shows that the $T x$. splendens mosquito can adapt to human activities. The success of $T x$. splendens originating from rubber plantations in the Banjarbaru area in adapting to the human environment, can be used as a biological control for Aedes sp mosquitoes in an integrated vector control program in residential areas (Thomas 2017; Leung et al. 2020).

In conclusion, $T x$. splendens can use a rubber sap bowl filled with water as a breeding site. The number of larval Tx. splendens in each bowl in the early development of instar is greater than 1 and decreases as the developmental phase progresses due to the limited volume of water in the bowl, cannibalism, and the number of other mosquito larvae as prey.

\section{REFERENCES}

Aditya G, Bhattacharyya S, Kundu N, Kar PK, Saha GK. 2007. Predatory efficiency of the sewage drain inhabiting larvae of Toxorhynchites splendens Wiedemann on Culex quinquefasciatus Say and Armigeres subalbatus (Coquillett) larvae. Southeast Asian J Trop Med Publ Health 38 (5): 799-807.

Altwegg, R. 2003. Hungry predators render predator-avoidance behavior in tadpoles ineffective. Oikos 100 (2): 311-316.

Amalia R, Nurkhoiry R, Oktarina SD. 2020. analisis kinerja dan prospek komoditas kelapa sawit. Radar: Opini dan Analisis Perkebunan 1 (1): 1-12. [Indonesian]

Benelli G, Jeffries CL, Walker T. 2016. Biological control of mosquito vectors: past, present, and future. Insects 7 (52): 1-18. DOI: 10.3390/insects7040052.

Boonklong O, Bhumiratana A. 2016. Seasonal and geographical variation of dengue vectors in Narathiwat, South Thailand. Can J Infect Dis Med Microbiol 2016: 8062360. DOI: 10.1155/2016/8062360.

Collins LE, Blackwell A. 2000. The biology of Toxorhynchites mosquitoes and their potential as biocontrol agents. Biocontrol News Inform 21 (4): 105-116.

Couret J, Notarangelo M, Veera S, LeClaire-Conway N, Ginsberg NS, LeBrun RL. 2020. Biological control of Aedes mosquito larvae with carnivorous aquatic plant, Utricularia macrorhiza. Parasites Vectors 13: 208 DOI: 10.1186/s13071-020-04084-4

Dida GO, Gelder FB, Anyona DN, Abuom PO, Onyuka JO, Matano AS, Adoka SO, Kanangire CK, Owuor PO, Ouma C, Ofulla AVO. 2015. Presence and distribution of mosquito larvae predators and factors influencing their abundance along the Mara River, Kenya and Tanzania. SpringerPlus 4: 136-150 DOI: 10.1186/s40064-015-0905-y

Dinithi D, Hemantha W. 2020. Co-occurrence of Lutzia fuscana and Aedes albopictus (Diptera: Culicidae) in native habitats: as an implication for biological control. Rajarata Univ J 5 (2): 52-58.

Donald CL, Siriyasatien P, Kohl A. 2020. Toxorhynchites species: a review of current knowledge. Insects 11: 747. DOI: 10.3390/insects 11110747

Eba K, Duchateau L, Olkeba BK, Boets P, Bedada D, Goethals PLM, Mereta ST, Yewhalaw D. 2021. Bio-Control of Anopheles mosquito larvae using invertebrate predators to support human health programs in Ethiopia. Intl J Environ Res Public Health 18: 1810. DOI: 10.3390/ijerph18041810

Endarto O, Wuryantini S. 2019. Predatory prey of Harmonia axyridis against Mizus persicae Aphids on citrus plants. Jurnal Agronida 5 (2): 45-50. [Indonesian]

Gowhar SA. 2018. Density of Chikungunya Vectors and Platynectes beetles in the rubber plantations. Biomed J Sci Tech Res 2 (1): 20662072. DOI: 10.26717/BJSTR.2018.02.000624

Jomon KV, Valamparampil TT. 2014. Medically Important Mosquitoes in the rubber plantation belt of Central Kerala, India. Southeast Asian J Trop Med Public Health 45 (4): 796-800.

Kaewwaen W, Bhumiratana D. 2015. Landscape ecology and epidemiology of malaria associated with rubber plantations in Thailand: Integrated approaches to malaria ecotoping. Interdisc Perspect Infect Dis 2015: 909106. DOI: 10.1155/2015/909106. 
Klecka J, Boukal DS. 2012. Who eats whom in a pool? a comparative study of prey selectivity by predatory aquatic insects. PLoS ONE 7 (6): e37741. DOI: 10.1371/journal.pone.0037741

Kumar NP, Bashir A, Abidha S, Sabesan S. Jambulingam P. 2014. Predatory potential of Platynectes sp. (Coleoptera: Dytiscidae) on Aedes albopictus, the vector of dengue/chikungunya in Kerala, India. Trop Biomed 31 (4): 736-741.

Kundu M, Sharma D, Brahma S, Pramanik S, Saha GK, Aditya G. 2014. Insect predators of mosquitoes of rice fields: portrayal of indirect interactions with alternative prey. J Entomol Zool Stud 2 (5): 97-103.

Leung K, Ras E, Ferguson KB, Ariëns S, Babendreier D, Bijma P, Bourtzis K, Brodeur J, Bruins MA, Centurión A, Chattington SR, Chinchilla-Ramírez M, Dicke M, Fatouros NE, González-Cabrera J, Groot TVM, Haye T, Knapp M, Koskinioti P, Le Hesran S, Lyrakis M, Paspati A, Pérez-Hedo M, Plouvie WN, Schlötterer C, Stahl JM, Thiel A, Urbaneja A, van de Zande L, Verhulst EC, Vet LEM, Visser S, Werren JH, Xia S, Zwaan BJ, Magalhaes S, Beukeboom LW, Pannebakker BA. 2020. Next-generation biological control: the need for integrating genetics and genomics. Biol Rev 95: 1838-1854. DOI: 10.1111 /brv.12641

Gvoždík L,Smolinský R. 2015. Body size, swimming speed, or thermal sensitivity? Predator-imposed selection on amphibian larvae. Evol Biol 15: 238 DOI: 10.1186/s12862-015-0522-y

Majumder A, Datta S, Choudhary BK Majumdar K. 2014. Do extensive rubber plantations influences local environment? A case study from Tripura, Northeast India. Curr World Environ 9 (3): 768-779. DOI: 10.12944/CWE.9.3.25

Millado JBH, Sumalde AC, Baldrias LR, Adorada JR, Caoili BL. 2017. Biology of a Philippine population of Toxorhynchites splendens (Wiedemann) (Diptera: Culicidae: Toxorhynchitinae) under laboratory conditions with Aedes aegypti (L.) (Diptera: Culicidae: Culicinae) as prey. Philipp Ent 31 (2): 85-105.

Millado JBH, Sumalde AC. 2018. Voracity and prey preference of Philippine population of Toxorhynchites splendens Wiedemann (Diptera: Culicidae) among Aedes Spp (Diptera: Culicidae) and Culex Quinquefasciatus Say (Diptera: Culicidae). Southeast Asian J Trop Med Publ Health. 49 (2): 240-250.

Mohamad N, Zuharah WF. 2014. Influence of container design on predation rate of potential biocontrol agent, Toxorhynchites splendens (Diptera : Culicidae) against dengue vector. Trop Biomed 31 (1): 166173.

Moirangthem BV, Singh SN Singh DC. 2018. Lutzia tigripes (Diptera: Culicidae, Metalutzia) for the mosquito larval control: A new prospect of mosquito control. Intl J Mosq Res 5 (6): 1-4

Muhamat, Hadisusanto S, Umniyati SR, Soesilohadi RCH. 2020. The Rubber Sap Bowl from Plastic Bottle Waste as Breeding Site Mosquito. Proceeding of International Conference on Science and Technology of Sustainable Industry, Banjarbaru, August 6-7 2020: 87-94. [Indonesian]

Nair DG, Gayathri VM. 2020. Ecology of dengue vector Aedes albopictus in the rubber plantation areas of a village in Palakkad district, Kerala. Intl J Mosq Res 7 (1): 4-7

Nasruddin, Bahri S. 2019. Studi Pengembangan Karet Alam Untuk Mangkok Penampungan Lateks Dari Pohon Karet. Prosiding Seminar National II Hasil Litbangyasa Industri Palembang, 26 Agustus 2019 129: 129-136 [Indonesian]

Odo GE, Agwu EJ, Haruna AS. 2015. Culicid forms distribution and breeding sites in Nsukka ecological zone of South Eastern Nigeria. J Parasitol Vector Biol ol 7 (5): 94-100. DOI: 10.5897/JPVB2015.0193

Payra A. 2020. A record of cannibalism in Ceriagrion coromandelianum Fabricius (Zygoptera: Coengrionidae). Revista de la Sociedad Entomológica Argentina 79 (4): 44-46. DOI: 10.25085/rsea.790407
Permata SH, Yotopranoto S, Kusmartisnawati. 2015. Effectiveness of Betta splendens as a biological predatory against Aedes aegypti larvae. Folia Medica Indonesiana 51 (4) : 268-271.

Pramanik S, Banerjee S, Banerjee S, Saha GK, Aditya G. 2016. Observations on the predatory potential of Lutzia fuscana on Aedes aegypti larvae: implications for biological control (Diptera: Culicidae). Fragmenta Entomologica 48 (2): 137-142 DOI: $10.13133 / 2284-4880 / 176$

Priyadarshana TS. 2021. Do predatory adult odonates estimate their adult prey odonates' body size and dispersal ability to proceed with a successful attack?. J Threat Taxa 13 (7): 18949-18952. DOI: 10.11609/jot.7198.13.7.18949-18952

Rahma N, Hasan H, Ratnasari A, Wahid I. 2020. The application of novel methods of animal barrier screen and kelambu trap for mosquitoe's surveillance in South and West Sulawesi, Indonesia. Biodiversitas 21 (10): 4787-94. DOI: 10.13057/biodiv/d211044

Saleeza SNR, Y Norma-Rashid Y, Sofin-Azirun M. 2014. Guppies as predators of common mosquito larvae in Malaysia. Southeast Asian J Trop Med Public Health 45 (2): 299-308

Shultza S, Finlayson LV. 2010. Large body and small brain and group sizes are associated with predator preferences for mammalian prey. Behav Ecol 21: 1073-1079 DOI: 10.1093/beheco/arq108

Soda KJ, Moore SM, España G, Bloedow J, Raybaud B, Althouse B, Johansson MA. 2018. DTK-Dengue: A new agent-based model of dengue virus transmission dynamics. BioRxiv1-34. DOI: $10.1101 / 376533$.

Tangena J-AA, Thammavong P, Lindsay SW, Brey PT. 2017. Risk of exposure to potential vector mosquitoes for rural workers in Northern Lao PDR. PLoS Negl Trop Dis 11 (7): e0005802. DOI: 10.1371/journal.pntd.0005802

Thomas M. 2017. Biological control of human disease vectors: a perspective on challenges and opportunities. BioControl 63 (1): 9-69. DOI 10.1007/s10526-017-9815-y

Tyagi B.K, Munirathinam A, Krishnamoorthy R, Baskaran G, Govindarajan R, Krishnamoorthi R, Mariappan T, Dhananjeyan KJ, Venkatesh A. 2015. A revision of genus Toxorhynchites Theobald, 1901, in the South-East Asian countries, with description of a new species Toxorhynchites (Toxorhynchites) darjeelingensis from West Bengal, India (Diptera, Culicidae). Haltered 6: 13-32.

Udayanga L, Ranathunge T, Iqbal MCM, Abeyewickreme W, Hapugoda M. 2019. Predatory efficacy of five locally available copepods on Aedes larvae under laboratory settings: An approach towards biocontrol of dengue in Sri Lanka. PloS ONE 14 (5): e0216140. DOI: 10.1371/journal.pone.0216140

Venkatesh A, Tyagi BK. 2015. Bradinopyga geminata (Anisoptera: Libellulidae) as a predator of Aedes aegypti immatures (Diptera: Culicidae). Intl J Mosq Res 2 (2): 98-105.

Younes A, El-Sherif H, Gawish F, Mahmoud M. 2015. Potential of Hemianax ephippiger (Odonata-Aeshnidae) nymph as predator of Fasciola intermediate host, Lymnaea natalensis. Asian Pac J Trop Biomed 5 (8): 671-675. DOI: 10.1016/j.apjtb.2015.04.008

Zahouli JBZ, Koudou BG, Muller P, Malone D, Tano Y, Utzinger J. 2017. Effect of land use changes on the abundance, distribution, and hostseeking behavior of Aedes arbovirus vectors in oil palm-dominated landscapes, southeastern Cote d'Ivoire. PLoS ONE 12 (12): e0189082. DOI: 10.1371/journal.pone.0189082

Zavortink TJ, Poinar GO. 2008. Toxorhynchites mexicanus, N. SP. (Diptera: Culicidae) from Mexican Amber: A new world species with old-world affinities. Proc Entomol Soc Washington 110 (1): 116-25. DOI: $10.4289 / 0013-8797-110.1 .116$ 